AperTO - Archivio Istituzionale Open Access dell'Università di Torino

Phenology of adult Stoneflies (Plecoptera) of the Curone stream (Northern Apennines, Italy)

This is a pre print version of the following article:

Original Citation:

Availability:

This version is available http://hdl.handle.net/2318/1728497

since 2020-02-19T11:39:20Z

Terms of use:

Open Access

Anyone can freely access the full text of works made available as "Open Access". Works made available under a Creative Commons license can be used according to the terms and conditions of said license. Use of all other works requires consent of the right holder (author or publisher) if not exempted from copyright protection by the applicable law. 


\section{Phenology of Adult Stoneflies (Plecoptera) of the Curone Stream (Northern Apennines, Italy)}

Tiziano Bo ${ }^{\text {a }}$, Stefano Fenoglio ${ }^{1}$, Manuel Jesús López-Rodríguez ${ }^{2}$ and José Manuel Tierno de Figueroa ${ }^{2}$

${ }^{1}$ University of Piemonte Orientale, Di.S.A.V., Via Bellini n. 25, 15100 Alessandria, Italy

2 University of Granada, Dep. Biología Animal, 18071 Granada, Spain 


\begin{abstract}
We studied the flight periods of 16 stonefly species from Curone stream (northern Appenines, Italy) and grouped them into four categories according to their flight periods autumnal (Protonemura salfii and Leuctra major), autumnal-winter (Leuctra fusca and Leuctra hexacantha), winter-spring (Leuctra hippopus and Leuctra subalpina), and spring (Besdolus ravizzarum, Isoperla grammatica, Perla grandis, Perla marginata, Brachyptera risi, Amphinemura sulcicollis, Protonemura intricata, Nemoura hesperiae, Capnioneura nemuroides and Leuctra handlirschi; probably D. cephalotes can also be added to this category, although no adults were observed). Among the adults, L. fusca was the most abundant species, while $C$. nemuroides was the rarest. There was partial temporal segregation in the flight periods. In general, the male flight period, at least in some species, occurred slightly in advance to the female flight period.

${ }^{\text {a }}$ Corresponding author. E-mail: tbo@unipmn.it
\end{abstract}

\title{
INTRODUCTION
}

Despite its short duration compared with the longer nymphal stage, the adult stage in stoneflies (Plecoptera) and some other aquatic insects is very important for the dispersion and re-colonization of the upper part of streams in compensation for nymphal drift (Hutchinson 1981, Brittain 1990, Tierno de Figueroa, Luzón-Ortega and Sánchez-Ortega 2003, Fenoglio et al. 2004). Thus, the study of adult phenology of these insects is fundamental to increase the knowledge of this important period of their life cycle.

Moreover, phenological studies acquire special interest nowadays because they can be used as a first signal of the global change effects. This is possible, because water temperature and photoperiod are the main factors regulating the emergence of aquatic insects, and Plecoptera in particular, in temperate areas (Corbet 1964, Hynes 1976, Sweeney 1984, Fenoglio et al. 2005 and 2008). Thus, the aim of the present work is to describe the flight periods of the Plecoptera species inhabiting a northern Apennine stream.

\section{METHODS AND MATERIALS}

The study was made in the Curone Stream (northwest Italy), near Fabbrica Curone ( $44^{\circ} 47^{\prime} 14^{\prime}$ ' $\mathrm{N}, 9^{\circ} 04^{\prime} 02^{\prime}$ ' E, $320 \mathrm{~m}$ a.s.l.). At the sampling station, the stream was a typical mountain Apennine lotic environment, with a 4.0-4.5 m width, coarse substrate, and riparian vegetation comprised Salix spp., Populus spp., and Robinia pseudoacacia. Riparian herbaceous vegetation comprised mainly Conium maculatum, Epilobium hirsutum and Asteraceae. This system shows a good environmental quality, reaching the First Class in the Italian Extended Biotic Index (Ghetti 1997), corresponding to an environment without trace of human-induced alteration. 
Adults were collected with an entomological net by sweeping the riparian vegetation and by directly picking individuals from the stones, through a transect of approximately five meters along both sides of the stream. At the sampling site, adults were collected on 17 dates from 13 April 2007 to 25 March 2008. On only one sampling occasion (27 July) were no adults collected. On 1 January 2008, a very small number of individuals was collected probably as a consequence of a stream flood.

The thermal regime of the site was assessed using a temperature datalogger, which recorded temperature every six hours through the year. Water temperature varied considerably during the study period, with a mean of $9.43{ }^{\circ} \mathrm{C}$, a minimum of $0.004{ }^{\circ} \mathrm{C}$ in December, and a maximum of $22.3{ }^{\circ} \mathrm{C}$ in July (Fig. 1).

\section{RESULTS AND DISCUSSION}

A total of 1,979 adult individuals was collected. Six families (among the European families, only Chloroperlidae was not present) and 16 species were recorded (Table 1). Nymphs of another species of Perlidae (Dinocras cephalotes) were collected in the stream, but not adults were captured during the sampling period. Nevertheless, we know from isolated collections made in prior years in this stream that this species presents a spring flight period pattern.

It was very apparent that the spring flight period species predominated, while exclusively summer and winter species were absent. A minor peak occurred in autumn. Nevertheless, while in summer no species were detected, some species (e.g., Leuctra hexacantha, Leuctra fusca, Leuctra subalpina, and Leuctra hippopus) showed flight periods extending into winter. In our study area, summer seemed to be the poorest period, as reported in other regions of low Apenninic and non-Apenninic areas (Ravizza and Ravizza Dematteis 1979, Nicolai and Fochetti 1983) and contrasted with what happens at high altitude, where delay in the flight periods of the spring species and advances of the autumnal ones cause a higher number of species flying in summer, as demonstrated also in other areas from southern Europe (e. g., Tierno de Figueroa et al. 2001). Probably, lotic systems of low altitude in the Apennines experience some environmental changes in summer, such as intermittent flow and warmer temperatures, which make oviposition impossible, as pointed out by Nicolai and Fochetti (1983).

When comparing the flight periods of the studied species in this area with their known adult phenology in Italy (Consiglio 1980, Fochetti and Tierno de Figueroa 2008), they are generally within the typical temporal range, although some spring species (e.g., Besdolus ravizzarum, Amphinemura sulcicollis, and Protonemura intricata) begin to fly one or two months earlier, and some typically autumnal species (e.g., L. fusca and L. hexacantha) showed an extended autumnal-winter flight period in our study area. These data can be explained by the relatively low flow and relatively high temperature of Curone Stream.

When comparing our results with those from another Apenninic stream, the Erro Stream (Ravizza 1976), we observed that the flight periods of spring species were nearly a month delayed in Curone Stream. On the other hand, when compared to Nure Stream (Ravizza and Ravizza Dematteis 1979), no consistent patterns were apparent, 
with some species presenting advanced flight periods and others with delayed ones. This could be a consequence of the different environmental characteristics (probably mainly thermal) and demonstrates why data on flight periods should be extrapolated only with extreme caution from certain areas to others.

As previously pointed out by others (e.g., Ravizza and Ravizza Dematteis 1979) in similar areas, the species showing longer flight periods are the autumnal ones. This is the case for $L$. fusca, and $L$. hexacantha in our study stream. L. fusca was the most abundant species that we found, which has been similarly noted for other low Apenninic areas (e.g., Ravizza and Ravizza Dematteis 1979, Nicolai and Fochetti 1983). Despite its abundance in the nymphal stage, D. cephalotes was not collected as an adult. There was a partial temporal segregation in the flight periods, especially if the large numbers of individuals among the species of the genus Leuctra are considered (Fig. 2), and this probably tends to diminish interspecific competition during the nymphal stage and may act as a barrier to mistaken identities of mates between closely related species (Illies 1952). Nevertheless, behavioral cues are used to ensure the correct mating encounters - cues such as the existence of aggregation sites and the employment of vibrational communication (Stewart 1994). This temporal segregation in adults of the Leuctra genus as been previously recorded in other areas (Tierno de Figueroa et al. 2002). Our data also show that, in general, the male flight period, at least in some species, occurs slightly in advance of the female one.

\section{ACKNOWLEDGEMENTS}

We are grateful to M. Cammarata, M. Grenna, and M. Pessino for help with the field work. This study was supported by A.T.F. - Alessandria grants.

\section{LITERATURED CITED}

Brittain, J.E. 1990. Life history strategies in Ephemeroptera and Plecoptera. Pages 1-12 In: Campbell, I.C. (ed.), Mayflies and stoneflies. Kluwer Academic Publishers, New York, USA.

Consiglio, C. 1980. Plecotteri (Plecoptera). Guide per il riconoscimento delle specie animali delle acque interne italiane. C.N.R., Verona, Italy. 68 pp.

Corbet, P.S. 1964. Temporal patterns of emergence in aquatic insects. Can. Entomol. 96:264-279.

Fenoglio, S., T. Bo, G. Gallina, and M. Cucco. 2004. Vertical distribution in the water column of drifting stream macroinvertebrates. J. Freshwat. Ecol. 19: 485-492.

Fenoglio, S., T. Bo, M. Battegazzore, and A. Morisi. 2005. Growth of Oligoneuriella rhenana (Imhoff, 1852) (Ephemeroptera: Oligoneuriidae) in two rivers with contrasting temperatures in NW Italy. Zool. Stud. 44:271-274.

Fenoglio, S., T. Bo, J.M. Tierno de Figueroa, and M. Cucco. 2008. Nymphal growth, life cycle, and feeding habits of Potamanthus luteus (Linnaeus, 1767) (Insecta: Ephemeroptera) in the Bormida River, Northwestern Italy. Zool. Stud.47:185-190.

Fochetti, R. and J.M. Tierno de Figueroa. 2008. Plecoptera. Vol. XLIII. Fauna d'Italia. Ed. Calderini, Bologna, Italy. 322 pp. 
Ghetti, P.F. 1997. Manuale di applicazione Indice Biotico Esteso (I.B.E.). Provincia autonoma di Trento, Trento. $222 \mathrm{pp}$.

Harper, P. and J.G Pilon. 1970. Annual patterns of emergence of some Quebec stoneflies (Insecta: Plecoptera). Can. J. Zool. 48:681-694.

Hutchinson, G.E. 1981. Thoughts on aquatic insects. BioScience 31:495-500.

Hynes, H.B.N. 1976. Biology of Plecoptera. Ann. Rev. Entomol. 21: 135-153.

Illies, J. 1952. Zwei neue arten der plecopterngattung Isoperla aus dem deutschem Mittelgebirge. Zool. Anz. 149:42-48.

Nicolai, P. and R. Fochetti. 1983. Faunistica, fenologia ed etologia dei plecotteri dei Monti della Tolfa (Antiappenino laziale) (Plecoptera). Frag. Entomol. 17:51-84.

Ravizza, C. 1976. Ricerche ecologica-faunistiche sui Plecotteri del Torrente Erro (Appennino Ligure). Boll. Mus. Civ. St. Nat. Verona 3:331-361.

Ravizza, C. and E. Ravizza Dematteis. 1979. I plecotteri del corso medio-inferiore del torrente Nure (Appennino Piacentino). Natura 70:193-217.

Stewart, K.W. 1994. Theorical considerations of mate finding and others adult behaviors of Plecoptera. Aquatic Insect 16:95-104.

Sweeney, B.W. 1984. Factor influencing life-history patterns of aquatic insects. Pages 56-100 In: Resh V.H and D.M. Rosenberg (eds.), The ecology of aquatic insects. Praeger Publishers, New York, USA.

Tierno de Figueroa, J.M., J.M Luzón-Ortega, and A. Sánchez-Ortega. 2001. Fenología de los Plecópteros (Insecta, Plecoptera) de Sierra Nevada (Granada, España). Zool. Baetica 12:49-70.

Tierno de Figueroa, J.M., J.M. Luzón-Ortega, and A. Sánchez-Ortega. 2003. Protandry and its relationship with adult size in some Spanish stoneflies species (Plecoptera). Ann. Entomol. Soc. Am. 96:560-562. 
Table 1. Adults of stonefly species collected near Curone Stream, northern Appenines, Italy during the period from 13 ApriI 2007 to 25 March 2008.

\begin{tabular}{|c|c|c|c|c|}
\hline \multirow{2}{*}{$\begin{array}{l}\text { Family } \\
\qquad \text { Species }\end{array}$} & \multirow[b]{2}{*}{ Date } & \multicolumn{2}{|c|}{ Number collected } & \multirow{2}{*}{$\begin{array}{c}\text { Temporal } \\
\text { flight period } \\
\text { group }\end{array}$} \\
\hline & & Females & Males & \\
\hline \multicolumn{5}{|l|}{ Perlodidae } \\
\hline \multirow[t]{3}{*}{ Besdolus ravizzarum } & 30 April & 2 & 2 & Spring \\
\hline & 10 May & 3 & 3 & \\
\hline & 17 May & 3 & & \\
\hline \multirow[t]{4}{*}{ Isoperla grammatica } & 10 May & 4 & 5 & Spring \\
\hline & 17 May & 3 & 4 & \\
\hline & 14 June & 1 & & \\
\hline & 21 June & 1 & 1 & \\
\hline \multicolumn{5}{|l|}{ Perlidae } \\
\hline \multirow[t]{2}{*}{ Perla grandis } & 10 May & 8 & 9 & Spring \\
\hline & 17 May & 1 & & \\
\hline \multirow[t]{4}{*}{ Perla marginata } & 10 May & 1 & 2 & Spring \\
\hline & 17 May & 1 & 12 & \\
\hline & 14 June & 9 & 32 & \\
\hline & 21 June & 6 & 13 & \\
\hline \multicolumn{5}{|l|}{ Taeniopterygidae } \\
\hline \multirow[t]{4}{*}{ Brachyptera risi } & 18 April & 2 & 1 & Spring \\
\hline & 30 April & 1 & & \\
\hline & 10 May & 2 & 2 & \\
\hline & 25 March & & 1 & \\
\hline \multicolumn{5}{|l|}{ Nemouridae } \\
\hline \multirow[t]{4}{*}{ Amphinemuria sulcicollis } & 13 April & 2 & 1 & Spring \\
\hline & 30 April & 1 & & \\
\hline & 10 May & 2 & 2 & \\
\hline & 25 March & & 1 & \\
\hline \multirow[t]{2}{*}{ Protonemura intricata } & 30 April & & 1 & Spring \\
\hline & 17 May & & 2 & \\
\hline Protonemura salfii & 10 October & 4 & & Autumn \\
\hline \multirow[t]{5}{*}{ Nemoura hesperiae } & 13 April & 4 & 7 & Spring \\
\hline & 18 April & 4 & 4 & \\
\hline & 30 April & 2 & & \\
\hline & 10 May & 1 & & \\
\hline & 17 May & 2 & & \\
\hline \multicolumn{5}{|l|}{ Capniidae } \\
\hline Capnioneura nemuroides & 13 April & 1 & & Spring \\
\hline
\end{tabular}




\begin{tabular}{|c|c|c|c|c|}
\hline \multicolumn{5}{|l|}{ Leuctridae } \\
\hline \multirow[t]{7}{*}{ Leuctra fusca } & 5 September & 6 & 2 & \multirow{7}{*}{ Autumn-winter } \\
\hline & 12 October & 218 & 212 & \\
\hline & 20 October & 229 & 214 & \\
\hline & 19 November & 30 & 42 & \\
\hline & 12 December & 12 & 2 & \\
\hline & 21 January & 5 & 3 & \\
\hline & 8 February & 3 & & \\
\hline \multirow[t]{6}{*}{ Leuctra handlirschi } & 13 April & 2 & 2 & \multirow[t]{6}{*}{ Spring } \\
\hline & 18 April & 1 & 1 & \\
\hline & 30 April & 1 & 2 & \\
\hline & 10 May & 5 & 6 & \\
\hline & 17 May & 39 & 24 & \\
\hline & 25 March & 6 & 10 & \\
\hline \multirow{6}{*}{ Leuctra hexacantha } & 5 September & 11 & 21 & \multirow[t]{6}{*}{ Autumn-winter } \\
\hline & 12 October & 69 & 12 & \\
\hline & 20 October & 9 & 3 & \\
\hline & 19 November & 2 & 1 & \\
\hline & 12 December & 1 & & \\
\hline & 21 January & 1 & & \\
\hline \multirow[t]{5}{*}{ Leuctra hippopus } & 13 April & 5 & 2 & \multirow[t]{5}{*}{ Winter-spring } \\
\hline & 18 April & 2 & & \\
\hline & 8 February & 1 & & \\
\hline & 11 March & 99 & 144 & \\
\hline & $25 \mathrm{March}$ & 41 & 49 & \\
\hline Leuctra major & 12 October & 8 & 2 & Autumn \\
\hline Leuctra subalpina & 30 April & 3 & & Winter-spring \\
\hline
\end{tabular}




\section{Caption to Figures}

Figure 1. Water temperature variation during the study period.

Figure 2. Seasonal succession in the flight period of the six Leuctra species collected in the Curone Stream. 
Fig. 1

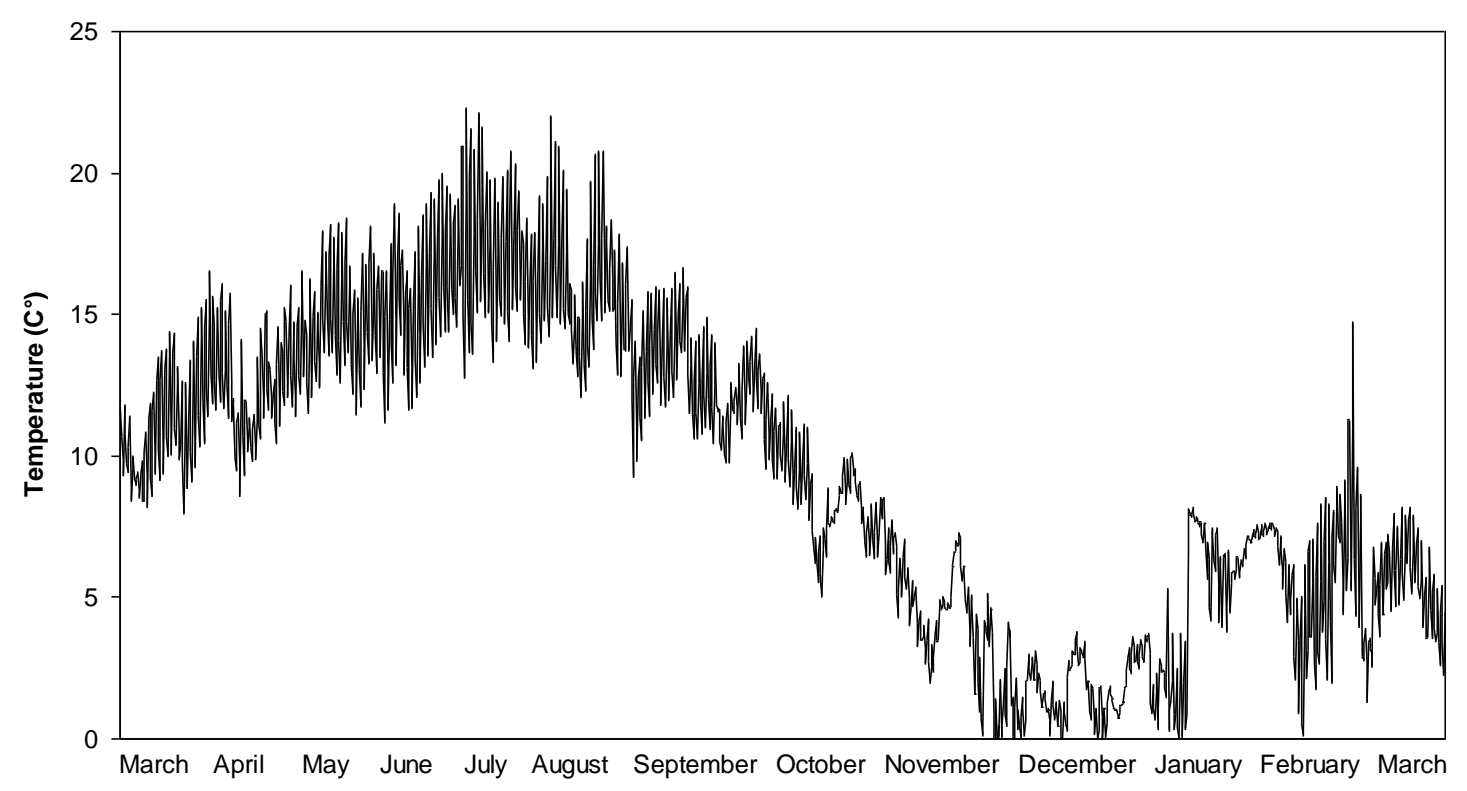


Fig. 2

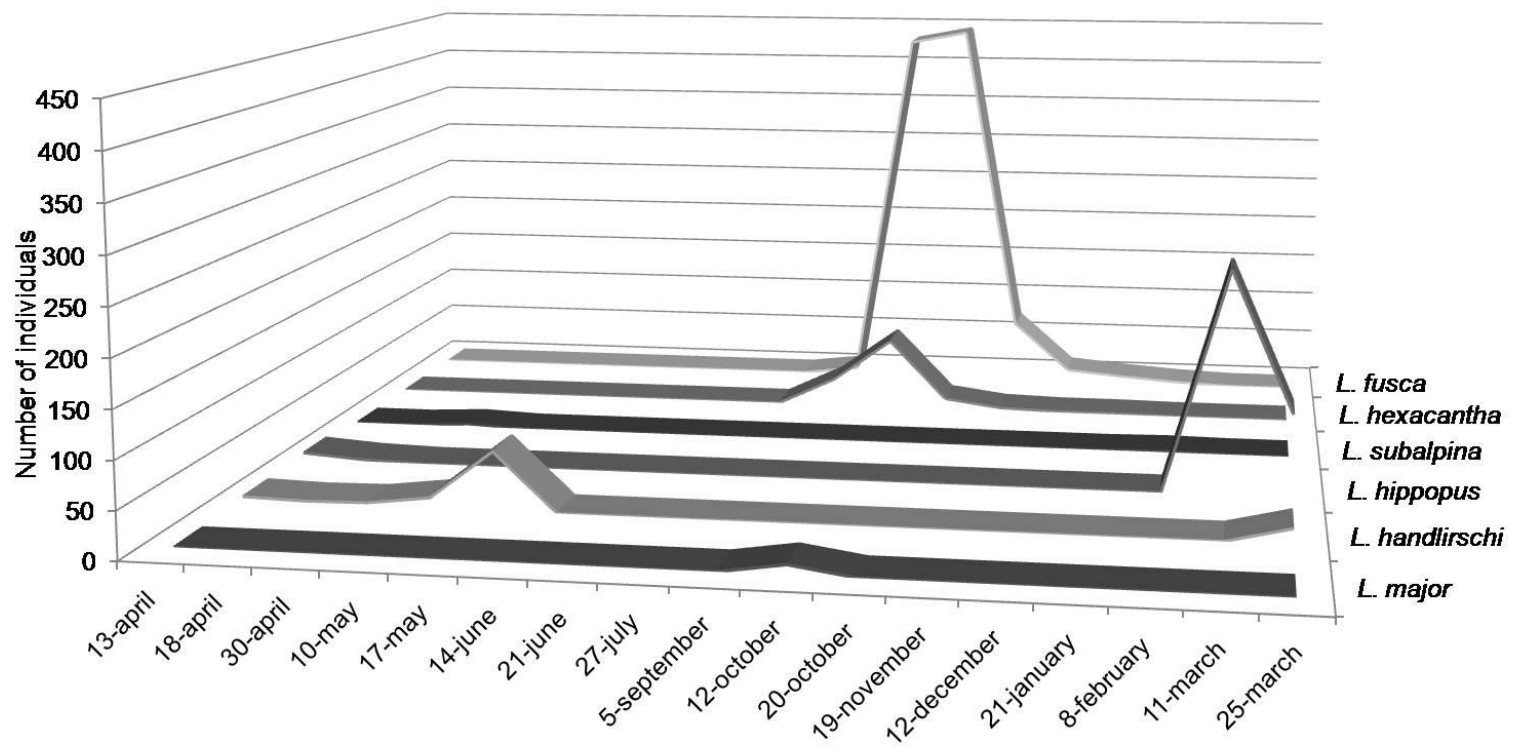

